\title{
Implementation of an Integrated Curriculum Through Special Class Programs
}

\author{
*Muhammad Achsin ${ }^{1}$, Amir Maliki Abitolkha ${ }^{2}$, M. Yunus Abu Bakar ${ }^{3}$ \\ ${ }^{1,2,3}$ Universitas Islam Negeri (UIN) Sunan Ampel, Jl. Ahmad Yani No.117, Jemur \\ Wonosari, Kec. Wonocolo, Surabaya, Indonesia \\ *achsinhaus45@gmail.com
}

\begin{abstract}
This study aims to determine how the curriculum's implementation is integrated through a unique class program in Madrasah Aliyah Waru Sidoarjo. This research includes qualitative research. The techniques used in data collection use observation methods, interviews and documentation. As for the data analysis techniques, the authors use qualitative descriptive analysis technique, which is the form of written and unwritten (oral) data from people and behaviours observed. In this case, the author seeks to describe Thoroughly the actual state. This research finds that the integrated curriculum at Madrasah Aliyah Fadlillah Waru Sidoarjo is a curriculum development that eliminates the boundaries between national subjects and TMI subjects. The development of this curriculum can be interpreted as an effort to stir two different curricula in one educational institution. To achieve the institution's goals, in addition to students mastering abilities in general (national) subjects, they can also master abilities in TMI subjects.
\end{abstract}

Penelitian ini bertujuan untuk mengetahui implementasi kurikulum terpadu melalui program kelas khusus di Madrasah Aliyah Waru Sidoarjo, penelitian ini termasuk penelitian kualitatif. Teknik yang dipakai dalam pengumpulan data menggunakan metode observasi, wawancara dan dokumentasi. Sedangkan untuk teknik analisis data, penulis menggunakan teknik analisis deskriptif kualitatif, yaitu berupa data-data yang tertulis dan tidak tertulis (lisan) dari orang dan perilaku yang diamati sehingga dalam hal ini penulis berupaya menggambarkan secara menyeluruh tentang keadaan yang sebenarnya. Hasil Penelitian ini menunjukkan bahwa kurikulum terpadu di Madrasah Aliyah Fadlillah Waru Sidoarjo merupakan pengembangan kurikulum yang menghilangkan batasan antara mata pelajaran nasional dan mata pelajaran TMI. Pengembangan kurikulum ini dapat diartikan sebagai upaya pengadukan dua kurikulum yang berbeda dalam satu institusi pendidikan. Untuk mencapai tujuan lembaga, selain menguasai kemampuan mata pelajaran umum (nasional), siswa juga dapat menguasai kemampuan mata pelajaran TMI.

Keywords: Implementation, Integrated Curriculum, Special Class Programs.

Received: Aug 4, 2021; Revised: Oct 7, 2021; Accepted: December 2, 2021 


\section{INTRODUCTION}

The curriculum is a set of plans and arrangements regarding the objectives, content and learning materials, and the ways used as guidelines for organizing learning activities to achieve specific educational goals (Syam, 2019). This particular goal is the goal of national education which is to develop the potential of students to become human beings who believe in and fear God almighty, have good morality, be healthy, knowledgeable, capable, creative independently, and become democratic citizens who are responsible for fibre (Ikhwan et al., 2020).

So that the curriculum used is by national education standards, the minister of national education of the Republic of Indonesia issued Minister of National Education Regulation number 22 of 2006 concerning content standards which include the basic framework and structure of the curriculum, learning load, educational calendar, competency standards and essential competencies. For educational institutions, including schools under the auspices of the Ministry of Religion, do not want to lose too, the Minister of Religion also issued Minister of Religion Regulation number 2 of 2008 concerning the content standards of Islamic and Arabic religious education in madrasah (Anggraini and Anwar, 2021).

Madrasah Aliyah Fadlillah is an Islamic educational institution that, besides being guided by the National Education Standards (SNP), also applies an integrated curriculum, which combines the national curriculum with the curriculum of TMI (Tarbiyatul Mu'allimin Al Islamiyah). Where the books used in this curriculum are mainly in Arabic because they are taken or imported directly from Pondok Modern Darussalam Gontor Ponorogo, this is one of the characteristics of Madrasah Aliyah Fadllillah and is a differentiator or differentiation from other Madrasah Aliyah.

In this Madrasah Aliyah, the education system adopts the Pondok Modern Darussalam Gontor education system. Still, the education system collaborates with the Ministry of National Education (Kemendikbud) or the Ministry of Religion (Kemenag). The education and teaching system are established in Madrasah Aliyah Fadlillah Waru Sidoarjo, where Grades 1-3 TMI are equivalent to Madrasah Aliyah. So inevitably, the headmaster of the Fadlillah school principal must, to the maximum extent possible, integrate the two curricula at once, namely TMI with Madrasah Aliyah.

Students of class X Madrasah Aliyah Fadlillah or equivalent to class 4 TMI (Tarbiatul Muallimin Al Islamiyah) have a Special class program in which there are new class X students. In the class, the students specifically learn the lessons that have been studied by friends who are equal to him at the Madrasah Aliyah level but have studied the Gontor curriculum since class VII-IX Madrasah Aliyah. In addition, the program also aims to develop Arabic language skills for new class X students who, in fact have tiny Arabic language lessons when they sit in Madrasah Aliyah. Based on the above problems, the existence of this program is expected that new students, especially class $\mathrm{X}$ MA, can learn the lessons that should be taken during the Tsanawiyah correctly and adequately so that they can catch up with the lessons or material of TMI left behind. 
Theoretically, by knowing and describing the implementation of an integrated curriculum through the Special class program in Madrasah Aliyah Fadlillah Waru Sidoarjo, this research is expected to be an opportunity for writers to know the extent of the theories that have been obtained in lectures to be applied in actual practice and practically (Ikhwan, Noh and Iman, 2020). In addition to references and reading libraries about issues related to the Special class program in Madrasah Aliyah Fadllillah Waru Sidoarjo and helpful information for institutions. To make it easier to understand and obtain a more precise and more comprehensive picture of the title of the journal that the author compiled, then, in this case, the terms contained in the title of this thesis will be explained: "Implementation of Integrated Curriculum through Special Class Program in Madrasah Aliyah Fadlillah Waru Sidoarjo". In order not to occur miss understanding in understanding that intention.

Meanwhile, according to Ikhwan, implementation is the elucidation of ideas, concepts, policies or innovations in practical action to make an impact, both in the form of changes in knowledge, skills and values and attitudes (Ikhwan, 2019). An integrated curriculum is a set of plans and arrangements regarding the objectives, content and learning materials, and methods used to guide learning activities to achieve specific educational goals (Drake and Reid, 2018). Whereas Integrated in English is integrated, which means to unite, combine. Thus, an integrated curriculum (integrated curriculum) incorporates learning materials from various kinds of lessons into one separate unit. The most important thing is not only the form of this curriculum but also its purpose. The roundness of subjects is expected to shape children into integrated individuals, that is, humans who are in harmony with their lives. What the school teaches is adapted to the lives of children outside of school. Lessons help children deal with life problems outside school (Ashari, Syam and Budiman, 2017).

A unique class program is defined as a unit or unit of activity which is the realization or implementation of a policy, takes place in a continuous program, and takes place in an organization involving a group of people. According to (Hamalik, 2019), a class is a group of people who do activities together who get the teaching from the teacher. Meanwhile, unique means seriously and continuously doing something to obtain optimal results. So, the particular class program is a teaching and learning activity carried out by a group of people or students in earnest with a continuous process to obtain optimal results (Utami and Fadhli, 2020).

Madrasah Aliyah Fadhlillah Waru Sidoarjo is one of the Islamic educational institutions located in Tambak Sumur, Waru, Sidoarjo, which has a Special class program in implementing the integrated curriculum. From the affirmation of the title above, this thesis writing can be interpreted as research that wants to know about implementing an integrated curriculum through a Special class program in Madrasah Aliyah Fadlillah Waru Sidoarjo. 


\section{METHOD}

This study aims to find out how the implementation of the curriculum is integrated through the unique class program in Madrasah Aliyah Waru Sidoarjo. This research includes qualitative research, as written by Nurul Ulfatin, that qualitative research was directed to study actual events in the field starting from activities, behaviour and all things that could be seen naturally (Ulfatin, 2015). Directly in the area, then the actual events that occur in the field are described in detail for descriptive analysis (Moleong, 2015), as explained by Sugiyono, that the data that has been obtained is then translated into data in the form of descriptions or descriptions in words and language (Sugiyono, 2015). The essence of this research is that researchers come directly to the field to conduct research, dig up as much data as possible for accurate analysis.

The techniques used in data collection use observation methods, interviews and documentation. In conducting observations or observations in the field, the author plays an observer. In addition to being an observer, the author also runs data collection using a direct interview method with the informant who competently with the data or information needed by the researcher. Among the informant that the researcher interviewed is the principal, Deputy head of curriculum and lecturers in intensive course programs. As for the data analysis techniques, the authors use qualitative descriptive analysis technique, which is the form of written and unwritten (oral) data from people and behaviours observed. In this case, the author seeks to describe Thoroughly the actual state.

\section{RESULT AND DISCUSSION}

Several things caused the integration of the two TMI and national curricula into an integrated curriculum in the Tsanawiyah Fadlillah Madrasah. The ideals of the founders of this institution since the founding of this Islamic educational institution (Madrasah Aliyah Fadlillah). These two ideologically different curricula can be run together by applying an integrated curriculum model. The implementation of the integrated curriculum is considered as one alternative curriculum that can deliver the character curriculum. The following is a detailed explanation of the two integrated curriculum.

\section{National Curriculum}

National Curriculum, the formal curriculum applied at Madrasah Aliyah Fadlillah Waru Sidoarjo, is the Education Unit Level Curriculum (KTSP) with its educational institution Madrasah Aliyah which has a legal umbrella under the Department of Religion. Education Unit Level Curriculum, better known as KTSP education, was born as a manifestation of the mandate of the Law of the Republic of Indonesia No. 20 of 2003 concerning the National Education System and Government Regulation of the Republic of Indonesia No. 19 of 2005 concerning National Education Standards. KTSP is defined as an operational curriculum that is compiled and implemented by each education unit. The education unit performs the Formulation of KTSP by observing and based on competency standards and essential competencies developed by the National Education Standards Agency (BSNP). 
Educational unit level educational objectives are formulated about the general goals of education. In Government Regulation number 19 of 2005 concerning National Education standards, article 26 stated that secondary education aims to increase intelligence, knowledge, personality, noble character, and the skills to live independently and follow further education (Febriansyah, 2017). The KTSP structure and content at the elementary and secondary education levels are set out in the content standards, which are developed from a group of subjects, including 1) Groups of subjects and morals, 2) Groups of subjects of citizenship and personality, 3) Groups of science subjects and technology, 4) Group of aesthetic subjects, 5) Group of physical subjects, sports and health. KTSP content includes some subjects whose breadth and depth are a learning burden for students in education units.

Besides that, local content and personal development activities are included in the curriculum content. The subjects and the time allocation for each education unit are listed in the curriculum structure listed in this standard. Local content is a curricular activity to develop competencies adjusted to the region's characteristics and potentials, including regional excellence. The material cannot be grouped into existing subjects (Abitolkha, 2014);(Afista and Bakar, 2021). Personal development activities are activities outside the subject area. Self-development aims to provide opportunities for students to develop and express themselves according to the abilities, talents, interests of each student by the conditions of the madrasa. This activity is guided and facilitated by counsellors, teachers and education staff who can be carried out in extracurricular activities.

The extra-curricular activities at Madrasah Aliyah Fadlillah include scouting, leadership training, KKF (Community Swimming Fadlillah), Papercut, Banjol Sholawat Art, Sports, Muhadloroh (3 languages Speech), and School Health Education. Learning hours for each subject are allocated as stated in the curriculum structure to manage the learning load. Time allocation arrangements for each topic in odd and even semesters in one academic year can be made flexibly with a fixed amount of study load (Novita and Bakar, 2021). Face to face activities is learning activities in the form of a process of interaction between students and educators. The burden of learning activities face to face hourly learning at Madrasa Tsanawiyah Fadlillah is 45 minutes. The face-to-face load per week is 48 hours of study.

\section{Tarbiyatul Mu'alimin Al Islamiyah Curriculum}

Tarbiyatul Mu'alimin Al Islamiyah Curriculum, the curriculum reflects the identity of educational institutions. It is the curriculum that distinguishes one school from another. The difference between high school and MA can be seen from the curriculum, not the building. Likewise, between public schools and madrassas. The Tarbiyatul Mu'alimin Al-Islamiyah curriculum, commonly abbreviated as TMI, is adopted from the KMI curriculum at Gontor Ponorogo Modern Darussalam Islamic Boarding School in East Java. The central vision of this curriculum is to prepare Islamic teachers, such as the meaning of the curriculum name itself Tarbiyatul Mu'allimin Al-Islamiyah, which means "Islamic Teachers Education" by prioritizing mental formation and inculcation of Islamic knowledge, which can later be helpful for society, Nation, Religion and State.

The contents of the curriculum and the composition of the TMI curriculum teaching program consists of $100 \%$ religious knowledge and $100 \%$ general knowledge. It means that the lessons learned at TMI are not known as the separation of knowledge 
between religion and general science, and both are a unified whole. This is evidenced by the structure of the Indonesian language curriculum in Indonesian which contains several available science subjects. The TMI curriculum is divided into several areas in the academic field, namely Arabic, Dirosah Islamiyah, Teacher Training, English, Science, Natural Sciences, and Social Knowledge.

The TMI curriculum contains at least study material and lessons on Pancasila through Citizenship Education, Indonesian Language, Mathematics, Natural Sciences and other General Sciences for Indonesian language lessons. For English-language lessons, including English Lesson, Grammar, Conversation, Vocabularies, Translation, Reading, Writing and Dictation. And for lessons in Arabic covering various fields ranging from Al Fiqh, Al Hadith, Mantiq Science, Al Muthola'ah, Bidayatul Hidayah, Balaghoh, Tauhid, Proposed Fiqh, Date of Adabul Lughoh, Mustholahul Hadith, Nahwu, Imla', Dinul Islam, Al Khot, Insya', Al Adyan, At Tafsir. Al Faroidh and primarily the At Tarbiyah or education taught from the beginning of class VII to class VIII with the peak of education is the AMAanawiyah At Tadrisiyah practice exam or teaching and learning practice for Final Year students at Madrasah Aliyah Fadlillah Waru. The teaching system used in the TMI curriculum includes the Direct Method and Khomsu Khathawat Tadris or the Herbert Spenser method.

In the language teaching method, one of them is to use the Direct Method method or commonly called the direct teaching method, sometimes called the natural method. Often used in learning foreign languages, this method refrains from using the native language of learners or regional languages and only uses the target language (Arabic and English). In teaching practice abstracted from the book Tarbiyah AMAanawiyah by the founder of Pondok Modern Gontor KH. Imam Zarkasyi, who is consistently used by madrassas as TMI, includes the Herbert Spencer method with his Khamsu Khatwat Tadris. The uniqueness of this methodology is in perfecting the learning process contained in I'dad Tadris (Teaching Preparation) and reinforced by Naqd Tadris (Teaching criticism) by the Musrifin (Guidance). Planning teaching and learning activities in an integrated curriculum at Madrasah Aliyah Fadlillah includes daily, monthly and annual planning. Daily planning activities include discipline control in class, checking teacher's teaching preparation (I'dad tadris yaumiyah), class control during the teaching and learning process and organizing guided night learning.

The monthly activity planning includes teacher meetings every month to equalize teachers' perceptions of the program and subsequent Madrasah steps led by the school principal and head of the foundation. Evaluation of teaching and learning for one month regarding the teacher, teaching discipline, controlling teaching preparation, meeting class leaders every Saturday to convey information on teaching and learning activities, a field in the class, delivering advice and announcements from the administration staff. And for planning the annual activities of the Madrasah Aliyah Fadlillah, creating a conducive environment, and adding student motivation, this yearly program also held a General Examination, Mid-Year Examination and End of Semester Exams. This activity begins with the implementation of shahfahi exams or oral exams consisting of Arabic language tests (Muhadasah, Muthola'ah, nahwu shorof, mahfudzot, mufrodzat and tarjamah and balaghah for class XI students), English (Conversation, Reading, Grammar, Vocabularies, translation and Dictation), and the Qur'an (Tajweed, AMAanawiyah Worship, Qouliyah Worship and daily prayers). The language of instruction in teaching and learning activities here uses Arabic and English, especially TMI subjects, while Indonesian is for general subjects. 
Teacher recruitment used by madrassas is professional teachers who follow their respective fields (Sunaryo, Sendayu and Syam, 2021). And alumni who have abilities in certain areas. And assisted by some Alumni, namely those who graduated but have had a service period of approximately two years. By using Tarbiyatul Mu'alimin Al Islamiyah, which means "Religious Teacher Education" (Syam and Arifin, 2017), the things emphasized in the TMI curriculum are in the At Tarbiyah field, which are taught to students from class VII to class VIII, with the systematic and continuous subject matter. So that the capacity of students' abilities in educational theories and teaching-learning practices is so strong, they are supported with educational materials in Arabic that are oriented towards education. His scientific development is a must for all members of the academic community to master Arabic and English. Through Arabic, it is hoped that they will be able to conduct Islamic studies through their sources, namely the Qur'an and Hadith and through English, they are expected to be able to study general and modern sciences, in addition to being a tool of global communication. The following is the structure of the National curriculum at Madrasah Aliyah Fadlillah Waru Sidoarjo for the Academic year 2018-2019:

Table 1. Structure of the National Curriculum at MA Fadlillah Waru sidoarjo Academic year 2018-2019

\begin{tabular}{|c|c|c|c|}
\hline \multirow{2}{*}{ Component } & \multicolumn{3}{|c|}{ Class and Time Allocation } \\
\hline & $\mathbf{X}$ & $\mathbf{X I}$ & XII \\
\hline \multicolumn{4}{|l|}{ A. Subjects } \\
\hline \multicolumn{4}{|l|}{ 1. Religious education } \\
\hline a. Al Qur'an Hadits & 2 & 2 & 2 \\
\hline b. Aqidah Akhlaq & 2 & 2 & 2 \\
\hline c. Fiqih & 2 & 2 & 2 \\
\hline e. S K I & 2 & 2 & 2 \\
\hline 2. PPKN & 2 & 2 & 2 \\
\hline 3. Indonesian & 4 & 4 & 4 \\
\hline 4. Arabic & 3 & 3 & 3 \\
\hline 5. English & 3 & 3 & 3 \\
\hline 6. Mathematics & 4 & 4 & 4 \\
\hline 7. Physics & 2 & - & - \\
\hline 8. Biology & 2 & - & - \\
\hline 9. Chemical & 2 & - & - \\
\hline 10. History & 2 & 3 & 3 \\
\hline 11. Geography & 2 & 3 & 3 \\
\hline 12. Economy & 2 & 4 & 4 \\
\hline 13. Sociology & 2 & 3 & 3 \\
\hline 14. Art and culture & 2 & 2 & 2 \\
\hline 15. PJOK & 2 & 2 & 2 \\
\hline 16. TIK & 2 & 2 & 2 \\
\hline 17. Skills/Foreign Languages & 2 & 3 & 3 \\
\hline \multicolumn{4}{|l|}{ B. Local content } \\
\hline 1. At-Tarbiyah & 1 & 1 & 1 \\
\hline 2. An Nahwu & 1 & 1 & 1 \\
\hline Total Hour Allocation & 48 & 48 & 48 \\
\hline
\end{tabular}




\section{Implementation of the Integrated Curriculum Through the Tarbiyatul Mu'alimin Al Islamiyah Special Class Program}

Madrasah Aliyah Fadlillah was founded in 2001. The early history of the madrasah was founded by the owner of the foundation, who wanted to create an institution that was beneficial to the people and the country. In this madrasa, the foundation owner applies an integrated curriculum for the institution, namely the national curriculum and the TMI curriculum. Although it has two curricula at once, all students must possess the competency to speak Arabic, both passive and active. In connection with this, the teaching system in this madrasa is always evaluated to improve its quality.

In 2009 when Madrasah Aliyah Fadlillah Waru Sidoarjo was led by Drs. Juari Matrufi released a new policy regarding the development of the Arabic language, especially for class $\mathrm{X}$ students or the equivalent of grade 4 TMI, namely the Special class program. The specific system referred to is the Arabic language development program held outside the teaching and learning program, namely in the afternoon from 16.00 to 17.00 and at night from 20.00 to 21.00 WIB with the distribution of 7 (Seven) meetings 60 minutes each week. With different materials. The material delivered to the Special Class program students is mainly taken from TMI curriculum books. Still, not all of the lessons taken are only a few lessons that support the development of the Arabic language. These materials are applied to meet the demands of achieving the objective of the integrated curriculum in the madrasa. Namely, the students can speak Arabic correctly and adequately. The materials include: 1) In the odd semester, this class only studies Arabic (Durrusulughoh), al Imla 'and An Nahwu. The goal is to only concentrate on developing Arabic. And it is felt that these materials are the most important in this program so that only a few are taken, but the understanding of the material is profound. 2) For an even semester this class will study Al Hadith, Al Mahfudzot At Tafsir and Mutholaah. The goal is to catch up with the material with regular class children who have taken three years before entering the Madrasah or class $\mathrm{X}$ who used to attend the Madrasah Aliyah at the institute. The teaching staff is the most crucial factor of the factors that exist in the teaching and learning process. Because of that, in the recruitment of the teaching staff, attention was paid not only to their professional abilities in the teaching and learning process but also to the teacher's abilities and social skills in the teaching and learning process.

As for the program, the Curriculum Representative explained that the teaching staff teaching in this class was teaching staff who were competent in the Arabic language field and other fields taught in this class. The number of instructors in this class is three teachers for particular class students and three for special class students. All the teaching staff are already very competent in the Arabic language field. The number of students and students felt sufficient with the number of six teachers for teaching and learning in this class. Because scientific realities like these increasingly show that scientific activity is scientific, it cannot be insulated based on religious beliefs.

A scientific physicist does not have to be able to read the Koran. Even if it can be better as long as the formula uses the correct scientific procedures, it is acceptable, and this has no theological consequences for Islam or non-Islam. As far as Islamic sciences, such as interpretation are understood as one science, a person must realise nahwu science, sorof science, mantiq science, balagah science, ma'ani science or Arabic language, and various other sets of Islamic sciences. as a theological necessity, 
but a scientific necessity, that a person can study interpretation if he understands the rules of the Arabic language and some of its supporting sciences.

Curriculum design and implementation is a system that forms a straight line about the meaning of implementation reflects the design, so it is crucial for teachers and other field actors involved in the teaching and learning process as the core curriculum to understand curriculum design correctly and adequately. The integrated curriculum used by Madrasah Aliyah Fadlillah is a curriculum containing a description of the field of study from the Ministry of National Education curriculum and the Ministry of Religion and the TMI curriculum presented in an interrelated manner as a whole and embraces the Long Life Education system.

The implementation of the integrated curriculum makes the madrasa a centre for the formation of learners' character and the development of students in their national academic fields or even in their TMIs because the learning time they take in the madrasa takes approximately eight hours, from 07.30 to 15.10 WIB (Fullday). In teaching, general materials refer to the Ministry of National Education and the Ministry of Religion, using textbooks from the Minister of National Education. Whereas the teaching of TMI materials refers to Pondok Modern Darussalam Gontor Ponorogo, using Arabic and English language textbooks. And in the schedule of student subjects which starts from 07.30 to $15.10 \mathrm{WIB}$, there is also no time separation between general (National) subjects and TMI subjects. To master the ability of the academic field, especially materials to the TMI, the mastery of Arabic and English is required. To drive the development of the language skills of principals, students implement a Special class program as a language development program for Specific students. The Special class program was implemented starting in 2009. Initially, this program was carried out during school hours in general, i.e. at 07.30-15.10 WIB, so that in addition to the new $\mathrm{X}$ class, students were learning particular TMI subjects. Unique program material they also learned material from the National curriculum. Because of the limited classrooms and the minimal number of new class $\mathrm{X}$ students, then in 2011, the madrasa required implementing this program outside the teaching and learning process at school hours as in the previous year.

So, this class directly learns the regular class X TMI material in Arabic during school hours and evenings or evenings to study TMI material used in Special class programs like the previous year. Then in 2013, the program was re-applied to school hours as in the last year. However, this program only runs for one year, and it changes again to be applied outside school hours until this new school year 2018-2019. The forms of evaluation in this Special class program are in 2 formats: inherent assessment and endof-semester assessment.

Inherent evaluation is conducted by the Special Class instructors of each group (male and female) which is carried out every time the chapter is completed in each lesson. While the end of semester evaluation is an evaluation to determine students' success regarding the learning material they get in the semester. This evaluation takes the form of almost the same as the final semester exams in general, but only subjects taught in the Special class program are tested. Because this Special Class program is outside the usual teaching and learning process, this evaluation is carried out before the final semester exams. All Special Program students can concentrate on preparing for the last semester exams like other regular students. 


\section{CONCLUSION}

The integrated curriculum at Madrasah Aliyah Fadlillah Waru Sidoarjo is a curriculum development that eliminates the boundaries between national subjects and TMI subjects. The development of this curriculum can be interpreted as an effort to stir two different curricula in one educational institution. To achieve the institution's goals, in addition to students mastering abilities in general (national) subjects, they can also master abilities in TMI subjects. The institute issued a policy to implement special class programs for class $\mathrm{X}$, namely the Special class program. This program plays an essential role in mastering students' ability in the academic field, especially TMI materials, the majority of which speak Arabic.

\section{REFERENCES}

[1] Abitolkha, A. M. (2014) 'Problematika Penyelenggaraan Pendidikan Islam (Pendekatan Manajemen Berbasis Sekolah)', TADRIS: Jurnal Pendidikan Islam, 9(1), pp. 111-131.

[2] Afista, Y. and Bakar, M. Y. A. (2021) 'Islamic Boarding School-Based Madrasah: Policy Efforts to Reform the Superior Education Model', Al-Hayat: Journal of Islamic Education, 4(2), pp. 199-209.

[3] Anggraini, Z. R. and Anwar, S. (2021) 'The Effect of Habituation of Dhuha on the Religiosity of Santri', Eddukasi: Jurnal Pendidikan Islam, 9(2), pp. 153-168.

[4] Ashari, R., Syam, A. R. and Budiman, A. (2017) 'The World Challenge Of Islamic Education Toward Human Resources Development', in Proceeding International Conference on Islamic Education (ICIED), pp. 169-175. Available at: http://conferences.uin-malang.ac.id/index.php/icied/article/view/451.

[5] Drake, S. M. and Reid, J. L. (2018) 'Integrated curriculum as an effective way to teach 21st century capabilities', Asia Pacific Journal of Educational Research, 1(1), pp. 31-50.

[6] Febriansyah, F. I. (2017) 'Compilation of Islamic Law as the Foundation for Education in the Context of Religious Life', EDUKASI: Jurnal Pendidikan Islam (e-Journal), 5(2), pp. 80-94.

[7] Hamalik, O. (2019) Dasar-dasar pengembangan kurikulum. Bandung: PT Remaja Rosdakarya.

[8] Ikhwan, A. (2019) 'Public Relations in an Islamic Perspective; Implementation Study at Madrasah', At-Turats: Jurnal Pemikiran Pendidikan Islam, 13(2), pp. $105-117$.

[9] Ikhwan, A. et al. (2020) 'Revitalization of Islamic Education Teachers in the Development of Student Personality', in 1st Borobudur International Symposium on Humanities, Economics and Social Sciences (BIS-HESS 2019), pp. 162-165.

[10] Ikhwan, A., Noh, M. A. C. and Iman, N. (2020) 'Implementation Of The TahfidzalQur'an Curriculumat The Tahfidz Malaysia Boarding School', Journal of Critical 
Reviews, 7(8), pp. 866-870.

[11] Moleong, L. J. (2015) Metode Penelitian Kualitatif. Bandung: Remaja Rosdakarya.

[12] Novita, A. and Bakar, M. Y. A. (2021) 'Konsep Pendidikan Esensialisme dalam Pembentukan Karakter Siswa pada Mata Pelajaran Pendidikan Agama Islam', Dirasat: Jurnal Manajemen dan Pendidikan Islam, 7(1), pp. 12-22.

[13] Sugiyono (2015) Metode Penelitian \& Pengembangan (Research and Development). Bandung: Alfabeta.

[14] Sunaryo, S. A., Sendayu, F. S. and Syam, A. R. (2021) 'Internalization of Huma Betang Cultural Values through Narrative Counseling for Elementary Education Students', JURNAL INDRIA (Jurnal Ilmiah Pendidikan Prasekolah dan Sekolah Awal), 6(1).

[15] Syam, A. R. (2017) 'Posisi Manajemen Kurikulum Dan Pembelajaran Dalam Pendidikan', Muaddib: Studi Kependidikan Dan Keislaman, 7(1), pp. 33-46.

[16] Syam, A. R. (2019) 'Guru dan Pengembangan Kurikulum Pendidikan Agama Islam di Era Revolusi Industri 4.0', TADRIS: Jurnal Pendidikan Islam, 14(1), p. 1. doi: https://doi.org/10.19105/tjpi.v14i1.2147.

[17] Syam, A. R. and Arifin, S. (2017) 'Kedudukan Manajemen Sumber Daya Manusia Pendidikan Islam di Era Globalisasi', AL-ASASIYYA: Journal Of Basic Education, 2(1), p. 1.

[18] Ulfatin, N. (2015) Metode Penelitian Kualitatif di Bidang Pendidikan: Teori dan Aplikasinya. Malang: Media Nusa Creative.

[19] Utami, P. S. and Fadhli, M. (2020) 'The Effects of Hybrid Learning and Flipped Classroom Methods in Increasing the Learning Independence of Students' Citizenship Course', in 1st Borobudur International Symposium on Humanities, Economics and Social Sciences (BIS-HESS 2019), pp. 482-484. 